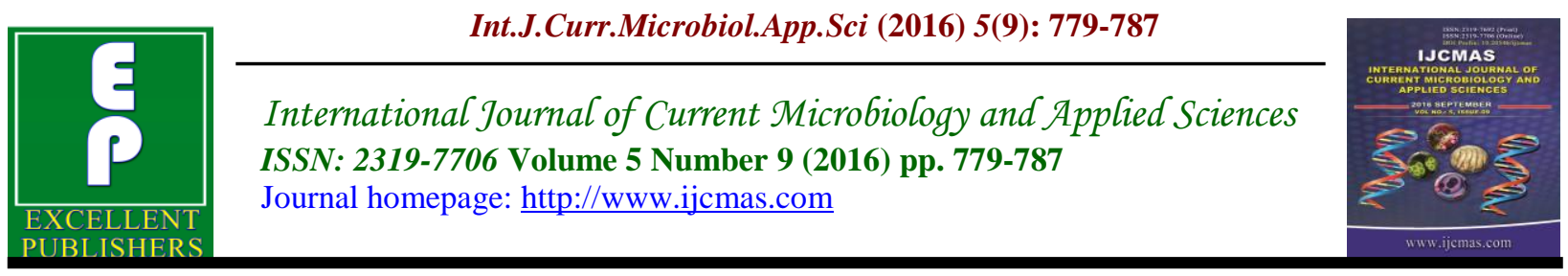

Original Research Article

http://dx.doi.org/10.20546/ijcmas.2016.509.089

\title{
Antibiotic Profile of Urinary Pathogens in a Tertiary Hospital, in Ekiti State, Nigeria
}

\author{
M.S. Odimayo ${ }^{1}{ }^{*}$, Joseph Adejoke Kadijat $^{1}$, S.I. Nwadioha ${ }^{2}$ and Olabiyi Olugbenga Enoch $^{1}$ \\ ${ }^{1}$ Department of Medical Microbiology and Parasitology, College of Medicine, Ekiti State \\ University, Ado Ekiti, Nigeria \\ ${ }^{2}$ Department of Medical Microbiology and Parasitology, College of Health Sciences, Benue \\ State University, Nigeria \\ ${ }^{3}$ Department of Medicine, College of Medicine, Ekiti State University Teaching Hospital, \\ Ado Ekiti, Nigeria \\ *Corresponding author
}

\begin{tabular}{|c|c|}
\hline \multirow{8}{*}{$\begin{array}{l}\text { Ke y w o r d s } \\
\text { Urinary tract } \\
\text { Infections, } \\
\text { pathogens, } \\
\text { sensitivity } \\
\text { patterns, } \\
\text { Nigeria. }\end{array}$} & \multirow{11}{*}{$\begin{array}{l}\text { Urinary tract infections (UTI) have the potential for serious and life-threatening } \\
\text { sequelae if left untreated or poorly treated. Empirical antibiotics treatment may be } \\
\text { warranted in the face of symptomatic infections pending availability of laboratory } \\
\text { results, hence the need to study the prevalent pathogen in a particular location and } \\
\text { its susceptibility pattern to enable healthcare providers make informed decision on } \\
\text { their choice of drug treatment for patients. We review } 1,658 \text { suspected cases of } \\
\text { Urinary Tract Infections analysed between January } 2014 \text { and September } 2015 \text { ( } 20 \\
\text { months) for bacterial isolates and their antibiotic susceptibility pattern. The results } \\
\text { showed that there were } 856 \text { females and } 802 \text { males. Majority of the males were >40 } \\
\text { years of age (55.49\%) while majority of the females were between } 21-40 \text { years age } \\
\text { group( } 62.74 \%) \text {. Organisms isolated include E.coli (54.42\%), Pseudomonas spp } \\
\text { (6.19\%), Klebsiella spp ( } 20.13 \%) \text {, Proteus spp (14.38\%), Enterococcus feacalis } \\
\text { (4.87\%) All isolates had some level of resistance to each antibiotic tested. } \\
\text { Ceftriaxone (65\%) showed highest level of sensitivity to E. coli, followed by } \\
\text { ofloxacin (58.5\%), ciprofloxacin (56.5\%), and levofloxacin (51.2\%). Lowest level } \\
\text { of sensitivity to erythromycin ( } 8.9 \%) \text { and cotrimoxazole (1.6\%) was seen among } \\
\text { isolates. All isolates were however found to have appreciable sensitivity to } \\
\text { Ofloxacin. E.feacalis isolate had } 100 \% \text { sensitivity to Ofloxacin, levonofloxacin, } \\
\text { and cotrimoxazole. in contrast to } 50 \% \text { sensitivity to Augmentin. The low level of } \\
\text { sensitivity seen in this study is not unconnected to the poor regulation of antibiotic } \\
\text { usage in our environment. This is a heavy challenge to the Ministry of Health and } \\
\text { other stakeholders in our health sector. }\end{array}$} \\
\hline & \\
\hline & \\
\hline & \\
\hline & \\
\hline & \\
\hline & \\
\hline & \\
\hline $\mathrm{Ar}$ & \\
\hline & \\
\hline & \\
\hline
\end{tabular}

\section{Introduction}

Urinary tract infection (UTI) is an inflammatory disease of any part of the urinary system namely: kidneys, ureters, bladder and urethra, secondary to microorganism invasion. UTI can be classified into lower or upper, depending on 
the site and organs involved; complicated and uncomplicated depending on the anatomy of the urinary tract; symptomatic and asymptomatic depending on the presence or absence of clinical manifestations, acute or chronic depending on the duration. UTI could also be recurrent or persistent (Fadeyi, 2010). UTI is a broad term that encompasses asymptomatic bacteriuria and symptomatic infection with microbial invasion and inflammation of the urinary tract. It is one of the most common clinical syndromes encountered in general and gynecological practices (IramShaifali et al., 2012). They are among the most common infections described in outpatients setting and hospital patients (IramShaifali et $a l ., 2012)$. Adult women (40-50\%) have a history of at least one episode of UTI in their lifetime (Urinary tract infection in women, 2016).

The pathogenesis of urinary tract infection involves ascending infection with bacteria colonizing the perineum in susceptible women. The normal urinary tract with the exception of urethral tract is resistant to colonization by bacteria and rapidly eliminates pathogenic and non-pathogenic micro-organisms that get access to the bladder. Uropathogenic clones of bacteria agents that cause infection in normal tract however have certain attributes which help them to invade the urinary tract and this include increased adherence to vaginal and uroepithelial cells, resistance to serum antibacterial activity, higher $\mathrm{K}$ antigen quantity, presence of aerobicin, presence of cytotoxic factor type 1 and heamolysin production (Walter, 2006).

Typical symptoms associated with UTI include the triad of dysuria, urgency and frequency, especially in adults. This might not be classically seen in the extremes of age. Neonates for instance might present with failure to thrive, vomiting and fever while elderly patients are majorly asymptomatic and some presents with shock. The symptoms a patient presents with are functions of the site involved in the infection with upper UTI presenting with fever and loin pains and lower UTI with lower abdominal pain or heaviness. Up to $90 \%$ of the patients with UTIs complain of urinary tract symptoms, one third or more of the patients with these symptoms however do not have bacteriuria (Medina-Bombardó et al., 2003). The most common symptoms for which most patients seek treatment are dysuria and frequency. Dysuria and frequency together raise the probability of UTI to more than $90 \%$, effectively ruling in the diagnosis by history alone. Presumptive diagnostic criteria of UTI include presence of leukocytes of $>5 / \mathrm{hpf}$ in microscopic examination of centrifuged urine, presence of bacteria in uncentrifuged urine, presence of red blood cells on urine microscopy, positive urine nitrite on dipstic, etc Isolation of the offending organism(s) via culture is however confirmatory.

There is public health issues associated with UTI with respect to quality of life. While not generally considered a cause of significant mortality, UTI do represent an important cause of morbidity. This is because UTI has the potential for serious and life-threatening sequelae if untreated or poorly treated. This is more likely to be the case where access to or availability of timely and appropriate medical intervention is limited due to inadequate numbers of health care providers, use of substandard drugs, missed diagnosis and lack of laboratory confirmation. Possible sequelae include ascending infection up to the level of the kidney (pyelonephritis), renal scarring and sepsis. UTI can be particularly dangerous in pregnant women in whom up to $50 \%$ of those with asymptomatic bacteriuria go on 
to develop pyelonephritis. In addition, these women experience higher rates of intrauterine growth retardation and low birth-weight infants. UTI has also been shown to increase the risk of preterm labour, premature delivery, preeclampsia, amnionitis and anemia in pregnancy (Okonko et al., 2010).

UTI occurs in all class and age groups of patients. It may be community acquired or nosocomial. The incidence increases with increasing age and patients on admission in hospitals have higher incidence than outpatients. A wide spectrum of microorganisms could be associated with UTI. Most are caused by bacterial agents. Majority of UTIs are caused by a single infecting agent especially in the first acute episode. Presence of more than 2 isolates in the sample suggests contamination. Prevalent organisms vary depending on geographical location and the antibiotic susceptibility of isolates varies. Many individuals with symptoms suggestive of UTI presenting to hospitals are likely to be started on empirical antibiotics pending availability of laboratory results, hence the need to study the prevalent organisms implicated in a particular location and the antibiotic susceptibility pattern.

\section{Methodology}

\section{Study design and population}

This is a retrospective study of 1,658 urine samples from patients with suspected UTI, submitted to Medical Microbiology laboratory, Ekiti State University Teaching Hospital (EKSUTH), Ado Ekiti between January 2014 and September, 2015.

\section{Study Location}

EKSUTH is located in Ado Ekiti, Ekiti state, south western, Nigeria. It is one of the 36 states of the federal republic of Nigeria. The state was created on the 1st of October, 1996 from Ondo state which itself was originally a part of the old western state. Ekiti state is located between latitudes $7 \hat{\mathrm{A}}^{\circ} 25^{\prime}$ and $80 \hat{\mathrm{A}}^{\circ} 5^{\prime} \mathrm{N}$ and longitudes $4 \hat{\mathrm{A}}^{\circ} 45^{\prime}$ and $5 \hat{\mathrm{A}}^{\circ} 46$ east (Local government areas in Ekiti state, 2014). It is a state bound in the north by Kwara and Kogi States, east by Edo state, west by Osun state and south by Ondo state. Agriculture is the main source of the state economy apart from the regular allocation from the federation account. The landscape is undulating with surrounding hills in a tropical climate with two seasons- rainy season (April to October) and dry season (November to March). Temperature ranges between $21^{0} \mathrm{C}$ to $28^{0} \mathrm{C}$. According to the national 2006 population census figure, Ekiti state has a population of 2,384,212 people constituting $1.703 \%$ of Nigerian population of 140,003,542 (Ekiti state population; Ekiti state population).

\section{Laboratory procedure}

Specimen: About $15 \mathrm{mls}$ of clean catch, mid-stream urine collected in a sterile universal bottle was sent to the laboratory within 2 hours of collection for microscopy, culture and sensitivity testing.

Processing: Macroscopic examination of the sample was done, observing the colour, presence of blood clots, turbidity and presence of foam. With a sterile calibrated wire loop, sample was inoculated on to CLED and blood agar plate, streaked and incubated aerobically overnight at $35-37^{\circ} \mathrm{c}$ and examined for evidence of growth after overnight incubation. Urine was centrifuged and loop-full of well mixed sediment was placed on a glass slide for microscopic examination. Presence of pus cells, urinary casts, red cells and yeast cells were noted. Antibiotic susceptibility testing was done 
following the modified Kirby Bauer method. This was done by emulsifying 1-2 colonies of isolates in normal saline at a turbidity compared to 0.5 Mac Farland's standard. Surface of Mueller - Hinton agar was swabbed with sterile cotton-tip swab soaked in emulsified isolate. Single antibiotic impregnated discs were placed on the agar surface at $25 \mathrm{~mm}$ apart and $20 \mathrm{~mm}$ from the plate edge and incubated at $35-37^{\circ} \mathrm{C}$ for 18 24 hrs. $^{12}$ Antibiotic discs tested were Augmentin $(20 / 10 \mu \mathrm{g})$, Gentamycin $(10 \mu \mathrm{g})$, Ciprofloxacin $(5 \mu \mathrm{g})$, Erythromycin $(15 \mu \mathrm{g})$, Ceftriazone $(30 \mu \mathrm{g})$, Ofloxacin $(5 \mu \mathrm{g})$, Cotrimoxazole $(1.25 / 23.75 \mu \mathrm{g})$, Levofloxacin $(5 \mu \mathrm{g})$ and Cefuroxime $(30 \mu \mathrm{g})$.

Control strains of Staphylococcus aureus (ATCC 25923) and Escherichiacoli (ATCC 25922) were used as gram-positive and gram-negative control, respectively. All procedures were done as recommended by the Clinical Laboratory Standard Institute (CLSI).

Interpretation: Growth limited to the primary inoculum was regarded as insignificant. Evidence of growth must be seen atleast on the primary streak line to be regarded as significant. Each significant isolate was identified by colonial morphology, gram staining and biochemical reactions. Samples from which more than 2 isolates were considered contaminated. Interpretation of the susceptibility testing was done by comparing the diameter of zone of inhibition with those of a standard table in three grades of susceptibility which are sensitive, intermediate and resistant.

Finding were analysed using the SPSS version 19software package for data analysis.

\section{Results and Discussion}

Out of the 1,658 cases reviewed, $856(51.6 \%)$ were females while $802(48.4 \%)$ were males. Majority of the males were above 50 years in age $(55.49 \%)$, while majority $(62.74 \%)$ of the females were between 21 and 40 years old (Table 1).

Table 2 showed the outcome of culture of samples tested. Seven hundred and seventyeight $(46.9 \%)$ of sampled specimen had no organism isolated, the growth in another 316 specimens $(19.1 \%)$ was not significant while a few $(0.6 \%)$ had mixed growth. Mixed growth was mostly seen among samples from female patients (80\%). S.aureus was isolated from 102 (6.1\%) patients while other pathogenic organisms were isolated from 452 specimens (27.3 $\%)$. The pathogenic organisms isolated were E.coli, which was in the majority $(54.4 \%)$, Klebsiella spp (20.1\%), Proteus spp (14.4\%), Pseudomonas spp (6.2\%)and the least frequent isolate was E.faecalis (4.9\%) (Figure. I).

Review of antibiotic susceptibility pattern (Table 3)showed that none of the E.feacalis was sensitive to gentamycin, ceftazidine and cefuroxime; sensitivity of Pseudomonas to antibiotics tested were very poor as none of the Pseudomonas spp was sensitive to erythromycin, cotrimoxazole, levofloxacin and cefuroxime while sensitivity to augmentin (7.1 \%), sensitivity to gentamycin $(28.6 \%)$ and ciprofloxacin $(35.7 \%)$ were low, however a fair sensitivities were seen to ofloxacin $(50 \%)$ and ceftriaxone $(42.9 \%)$. Ceftriaxone $(65 \%)$ showed highest level of action against $\mathrm{E}$. coli, followed by ofloxacin (58.5\%), ciprofloxacin (56.5\%), and levofloxacin $(51.2 \%)$ while lowest level of sensitivity was seen to erythromycin $(8.9 \%)$ and cotrimoxazole (1.6\%) among E coli isolates.

All isolates were found to have appreciable sensitivity to Ofloxacin. Most had appreciable sensitivity to ceftriaxone. 
E.feacalis isolate had $100 \%$ sensitivity to ofloxacin, levonofloxacin, and cotrimoxazole in contrast to $50 \%$ sensitivity to Augmentin. While none of the Proteus spp isolated was sensitive to erythromycin and cotrimoxazole, they were sensitive to ceftriaxone and levofloxacin (78.5\% each). Klebsiella spp were most sensitive to gentamycin $(64.8 \%)$. (Table 2)

UTI is a common disease in the tropics, especially among the female sex and at extremes of age. As reported in this study, female subjects $(51.63 \%)$ were more prone to UTI than males. This observation can be explained by the anatomy of the women urethra and its proximity to the anus which favour the faecal and skin flora easy access to the urethra. In this study, the incidence of UTI peaks between age 20years and 40years in females and above 49years of age in males. Similar to other findings, generally, the females are reportedly more prone to UTI than their male counterpart and the likelihood of developing UTI increases with age. Definitive diagnosis of UTI is dependent on the demonstration of the presence of an isolate although in some cases the causative organisms are not cultivable and in some cases the organisms are not recovered. The presumptive diagnosis of UTI in practice is mostly clinical, confirmation of which is done in the laboratory but in most cases, the organism are not recovered. As seen in this study, $778(46.9 \% ; \quad \mathrm{p}<0.001)$ of all samples examined yielded no isolate. This is probably due to misuse of antibiotics due to availability of antibiotics as over the counter drugs in Nigeria thereby encouraging indiscriminate antibiotic use before patients' presentation at the hospital for clinical assessment, sample collection and treatment. In most part of the country, today, antimicrobial drugs are widely used with or without prescription by appropriately qualified personnel resulting in inappropriate use of the various available antibiotics. Unfortunately, the overuse and misuse of these drugs resulted in the adaptation and resistance of these bacterial to the inhibitory effects of antibiotics (Okwori et al., 2011). Likewise, many clinicians will start a patient on empirical antibiotics once signs and symptoms are suggestive of UTI without recourse to the laboratory only to request much later for laboratory diagnosis when patient failed to respond to treatment.

Most UTIs are ascending infections of bacteria that colonize the vaginal wall and eventually the urethra. UTIs have been reported to be majorly caused by Gramnegative enterobacteriaceae with $E$. coli being the most prevalent. However, $S$. aureus as etiologic agent of UTI raises a lot of questions. The occurrence of Staphylococcus aureus isolation was significant, reflecting a deficiency in the knowledge of how to properly collect urine samples in a way that is void of contamination.

The significance of S.aureus isolate can be queried being a normal flora of the urinary tract. Specimen not properly collected can be contaminated by the flora of the urethra; commonest of such contaminant is the Staph aureus. Most users of the clinical microbiology laboratory do not instruct patients on how to properly and appropriately collect urine samples for analysis, making specimen submitted to the laboratory prone to contamination and giving room for confusion in internal quality control and reporting of results by pathologists. The isolate may be a true pathogen, however, in this study, most of the samples with $S$ aureus growth have no corresponding inflammatory response 
suggestive of UTI during microscopic examination of the urine specimens (less than 4-5 WBCs per high power field) making the isolation of $S$. aureus in this samples of doubtful significance.

Table.1 Demographic characteristics of the study population

\begin{tabular}{lllll}
\hline AGE GROUP & MALE $(\%)$ & FEMALE $(\%)$ & TOTAL $(\%)$ & $\chi^{2}(p$ value $)$ \\
\hline $0-5$ & $47(5.86)$ & $48(5.61)$ & $95(5.73)$ & \\
$6-10$ & $57(7.11)$ & $55(6.43)$ & $112(6.76)$ & \\
$11-15$ & $49(6.11)$ & $45(5.26)$ & $94(5.67)$ & \\
$16-20$ & $25(3.12)$ & $30(3.5)$ & $55(3.32)$ & \\
$21-30$ & $91(11.35)$ & $306(35.75)$ & $397(23.94)$ & \\
$31-40$ & $88(10.97)$ & $231(26.99)$ & $319(19.24)$ & \\
$>40$ & $445(55.49)$ & $141(16.47)$ & $586(35.34)$ & \\
TOTAL & $802(100 \%)$ & $856(100 \%)$ & $1658(100 \%)$ & $337.516\left(<0.0001^{*}\right)$ \\
\hline
\end{tabular}

$\chi^{2}$ : Chi square; $*: p$ value $<0.05$

Table.2 Outcomes of culture of Urine samples of patients with suspected UTI

\begin{tabular}{lcccc}
\hline TYPES OF GROWTH & $\begin{array}{c}\text { MALES } \\
\mathrm{n}(\%)\end{array}$ & $\begin{array}{c}\text { FEMALE } \\
\mathrm{n}(\%)\end{array}$ & $\begin{array}{c}\text { TOTAL } \\
\mathrm{n}(\%)\end{array}$ & $\chi^{2}(p$ value $)$ \\
\hline NO GROWTH & $450(56.1)$ & $328(38.3)$ & $778(46.9)$ & $58.904\left(<0.001^{*}\right)$ \\
NO SIGNIFICANT GROWTH & $142(17.7)$ & $174(20.3)$ & $316(19.1)$ & \\
MIXED GROWTH & $2(0.2)$ & $8(0.9)$ & $10(0.6)$ & \\
S. aureus & $36(4.5)$ & $66(7.8)$ & $102(6.1)$ & \\
PATHOGENIC ISOLATES & $172(21.5)$ & $280(32.7)$ & $452(27.3)$ & \\
TOTAL & $802(100.0)$ & $856(100.0)$ & $1,658(100.0)$ & \\
\hline
\end{tabular}

$\chi^{2}$ : Chi square; $*: p$ value $<0.05$

Table.3 Sensitivity pattern of significant bacteria isolates

\begin{tabular}{|l|l|l|l|l|l|l|l|l|l|}
\hline \multicolumn{7}{|l|}{ ANTIBIOTICS } \\
\hline BACTERIA & Aug(\%) & Gent(\%) & Ery(\%) & Ceft(\%) & Oflox(\%) & Cipro(\%) & Cotri(\%) & Levo(\%) & Cefu(\%) \\
\hline $\begin{array}{l}\text { E.coli } \\
\mathrm{N}=246\end{array}$ & $6(34.9)$ & $139(56.5)$ & $22(8.9)$ & $160(65)$ & $44(58.5)$ & $135(56.5)$ & $4(13.8)$ & $126(51.2)$ & $110(45)$ \\
\hline $\begin{array}{l}\text { Kleb spp } \\
\text { N=91 }\end{array}$ & $26(28.6)$ & $59(64.8)$ & $6(6.6)$ & $55(60.4)$ & $50(54.9)$ & $47(51.7)$ & $7(7.7)$ & $49(53.8)$ & $27(29.7)$ \\
\hline $\begin{array}{l}\text { E. feacalis } \\
\mathrm{N}=22\end{array}$ & $11(50)$ & $0(0.0)$ & - & $0(0.0)$ & $22(100)$ & - & $22(100)$ & $22(100)$ & $0(0.0)$ \\
\hline $\begin{array}{l}\text { Pseudomonas } \\
\text { spp } \mathrm{N}=28\end{array}$ & $2(7.1)$ & $8(28.6)$ & $0(0.0)$ & $12(42.9)$ & $14(50)$ & $10(35.7)$ & $0(0.0)$ & $0(0.0)$ & $0(0.0)$ \\
\hline $\begin{array}{l}\text { Proteus spp } \\
\text { N=65 }\end{array}$ & $18(27.7)$ & $36(55.4)$ & $0(0.0)$ & $51(78.5)$ & $36(55.4)$ & $33(13.4)$ & $0(0.0$ & $51(78.5)$ & $22(33.9)$ \\
\hline
\end{tabular}


Fig.1 Pathogenic isolates from samples

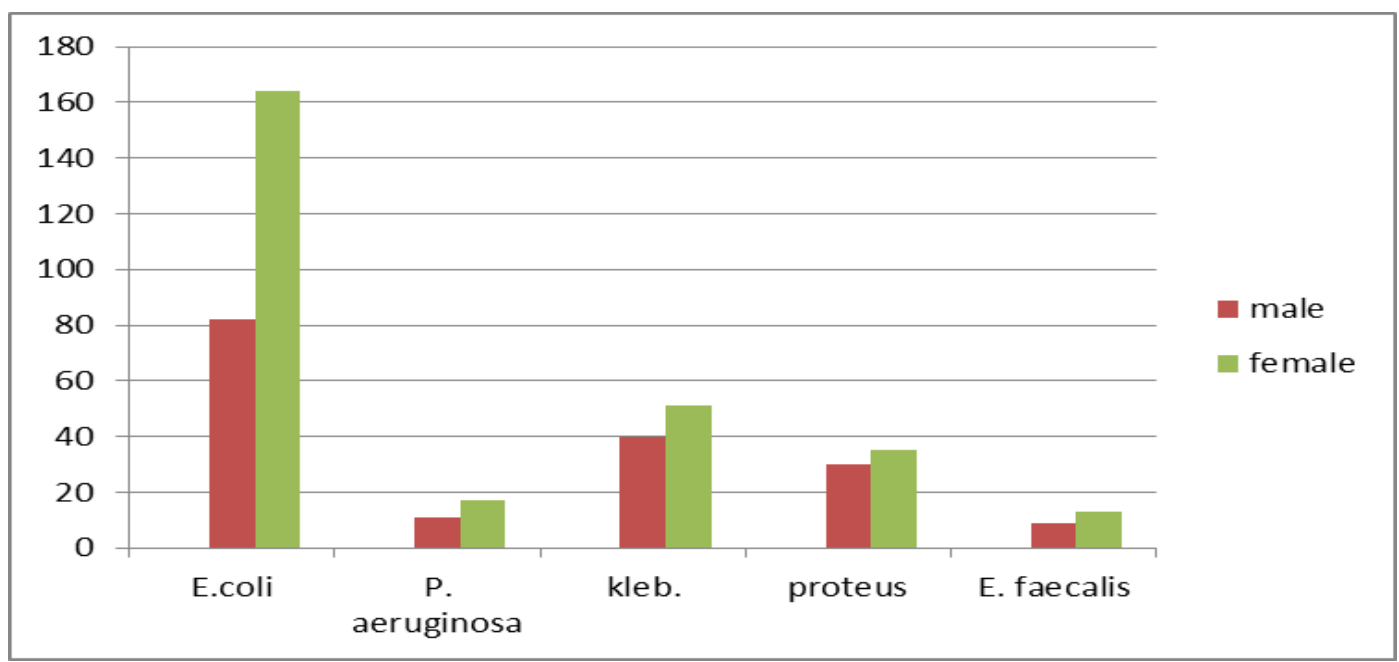

A significant relationship ( $\mathrm{p}$ value $<0.001)$ was found between the types of growth and the gender in this study. Pathogenic isolates was found in about $33 \%$ of females as compared to $22 \%$ of males. However, cultures with no growth were higher in males $(56 \%)$. The other pathogenic organisms implicated in UTI in this study are GNB enterobacteriaceae family especially E.coli which was significantly higher in urine samples of both males $(47.7 \% ; \mathrm{p}<0.001)$ and females $(58.6 \%$; $\mathrm{p}<0.001)$ compared with other isolates.

This is similar to findings in previous studies in which Gram-negative bacteria, particularly E. coli was the most implicated pathogen isolated in patients with UTIs (Burbige et al., 1984; Akinyemi et al., 1997; Okonofua et al., 1989). Findings contradict the report of Omonigho et al., (2001)who found Klebsiella spp. to be more prevalent than E. coli in UTIs. This result compares favourably with the findings of other workers who found $E$. coli more predominant over Klebisella spp. in similar studies in UTIs (Delzell, 2000; De-Mouy et al., 1988; Farooqui et al., 1989). GI commensals, E.coli being one of them are implicated in UTI due to the anatomic proximity of the GI tract to the urinary tract. In view of this, poor personal hygiene has been pencilled as a risk factor in UTI.

Other pathogens isolated in order of prevalence include Klebsiella spp., $P$. mirabilis, $P$. aeruginosa, and $E$. feacalis. This is in keeping with the findings of Anyamene et al., (2002) that the dominant etiologic agents accounting for more than $85 \%$ of cases of UTIs are the Gram-negative bacilli which are normal flora of the intestinal tract. The prevalence of UTI varies with the gender and age of the patient. In neonates and infants, UTIs are more common in males but by school age, all through to adulthood, higher prevalence is seen in the females. By far the most common population at risk for UTI is the sexually active female. The pathogens causing however does not vary with gender or age except in 'honeymoon cystitis' caused majorly by Staphylococcus saprophyticus (Washington et al., 1997).

The high rate of resistance to antibiotics which was also noted among common urinary isolates in this study is similar to what was reported in a study done in Benue where a general resistance was recorded in 
urinary isolates especially to Ampicillin, Tetracycline and Co-trimoxazolein both AIDS and non-AIDS patients. This is probably due to the indiscriminate use of antibiotics which can be easily procured over the counter without a clinicians authorised prescription.

In conclusion, there is a high level suspected UTI which could not be confirmed by culture most likely due to indiscriminate use of antibiotics in our environment. E.coli is still the most common bacteria pathogen seen in UTI in this environment. The peak incidence of UTI was seen between age 2040years in females and above 40years in males in this study. There is a high level of antibiotic resistance by isolated pathogens.

\section{Recommendation}

With the emerging trend of antibiotic resistance noted in this study, judicious and rational use of antibiotics is a must if we must avert the impending disaster of massive resistance to antimicrobial agents.

\section{References}

About Ekiti State. (Accessed at http://www.ekiti.com/AboutEkiti/about ekiti.html )

Adebola Onanuga and Godwin Oghenekparobo, A. 2012. Antimicrobial resistance of Staphylococcus aureus strains from patients with urinary tract infections in Yenagoa, Nigeria. J. Pharm. Bioallied Sci., 4(3): 226-230.

Akinyemi, K.O., Alabi, S.A., Taiwo, M.A., Omonigbehin, $\quad$ E.A. 1997. Antimicrobial susceptibility pattern and plasmid profiles of pathogenic Bacteria isolated from subjects with urinary tract infections in Lagos, Nigeria. Nigeria Quarterly J. Hosp. Med., 1: 7-11
Ayhan, N., Basbug, N., Ozturk, S. 1988. Causative agents of urinary tract infections and sensitivity to antibiotics. Microbiol. Bull., 22(3): 215-221.

Bent, S., Nallamothu, B.K., Simel, D.L., Fihn, S.D., Saint, S. 2002. Does this woman have an acute uncomplicated urinary tract infection? JAMA, 287(20): 2701-10.

Burbige, K.A., Retik, A.B., Colony, A., Bauer, S.B., Lebowitz, R. 1984. UrinaryTract Infection in boys. $J$. Urol., 132: 541-542.

Cheesbrough, M. 2002. Medical laboratories manual for tropical countries 2: 479.

Clinical Laboratory Standard Institute 2006. Performance standard for antimicrobial disk susceptibility tests; Approved standard $-9^{\text {th }}$ Ed. Supplement M2 - A9, 26(1).

Delzell JE (2000). Urinary tract infections in pregnancy. Am. Acad. Fam. Phys. p. 721.

De-Mouy, D., Aurioc, J.C., Declereq, G., Meyran, M., Durand, D.T., Bandeer, H., Lefevre, M. 1988. The frequency isolating urinary infection germs at a community practice and their sensitivity to various antibiotics. Pathol. Biol. Paris, 36(8): 1011-1015.

Ekiti state population. (Accessed at http://ekitistate.gov.ng/aboutekiti/population-figures.)

Fadeyi, A. 2010. Urinary Tract Infections. Microbiology. Boaz Adegboro (Ed). Ibadan: Ibadan University Press.

Farooqui, B.J., Khurshid, M., Alam, M. 1989. Urinary Tract Infection.JPMA-J. Pak. Med. Asso., 39(5): 129-131.

IramShaifali, Uma Gupta, Syed EsamMahmood, Jawed Ahmed. 2012. Antibiotic Susceptibility Patterns of Urinary Pathogens in Female Outpatients. N. Am. J. Med. Sci., 4(4): 163-169.

Local government areas in Ekiti state. 
(Accessed www.the.nigeria.com/2014/05/localgovernment-areas-in-ekiti-state.html.) Medina-Bombardó, D., Seguí-Díaz, M., Roca-Fusalba, C., Llobera, J. 2003. What is the predictive value of urinary symptoms for diagnosing urinary tract infection in women?.dysuria team Fam Pract., 20(2): 103-7.

Obiogbolu, C.H., I.O. Okonko, C.O. Anyamere, A.O. Adedeji, A.O. Akanbi, A.A. Ogun, J. Ejembi and T. O.C. Faleye. Incidence of Urinary Tract Infections (UTIs) among pregnant women in Akwa metropolis, Southeastern Nigeria. Scientific Res. Essay, Vol. 4 (8) pp. 820-824.

Okonko, I.O., Ijandipe, L.A., Ilusanya, A.O., Donbraye-Emmanuel, O.B., Ejembi, J., Udeze A.O., Egun O.C., Fowotade A. and Nkang, A.O. 2010. Detection of Urinary Tract Infection (UTI) among pregnant women in Oluyoro Catholic Hospital, Ibadan, South-Western Nigeria. Malaysian J. Microbiol., Vol 6(1): pp. 16-24.

Okonofua, E.E.A., Okonofua, B.N. 1989. Incidence and Pattern of Asymptomatic Bacteriuria of Pregnancy in Nigerian Women. Nig. Med. Pract., 17: 354358.

Okwori, E.E., Nwadioha, S.I., Jombo, G.T.A., Nwokedi, E.P., Odimayo, M.S. 2010. A Comparative Study of Bacterial Isolates from the Urine Samples of AIDS and non-AIDS Patients in Benue, Nigeria.2010. Asian Pacific J. Trop. Med., 3: 5, p P382 385.

Okwori, E.E., S.I. Nwadioha, E.O.P.
Nwokedi, M. Odimayo, G.T.A. Jombo. 2011. Bacterial Pathogens And Their Antibiotic Susceptibility Pattern In Idoma Community, Benue State Of Nigeria. emedpub - Int. Infect. Dis., Vol 1: 5.

Omonigho, S.E., Obasi, E.E., Akukalia, R.N. 2001. In vitro Resistance of Urinary Isolates of Escherichia coli and Klebsiella species to Nalidixic Acid. Niger. J. Microbiol. 15(1):25-29.

Onifade, A.K., Omoya, F.O., Adegunloye, D.V. 2005. Incidence and control of urinary tract infections among pregnant women attending antennal clinics in government hospitals in Ondo State, Nigeria. J. Food Agric. Environ., 3(1): 37-38.

Population of the Nigerian states. (Accessed at http://en.wikipedia.org/ wiki/listofNigeriastatesbypopulation.)

Urinary tract infection in women. Available at

http://umm.edu/health/medical/altmed/ condition/urinary-tract-infection-inwomen. Accessed on $13^{\text {th }}$ mar, 2016

Walter, E., Stamm, Theodore, E., Woodward. 2006. Award: HostPathogen Interactions in CommunityAcquired Urinary Tract Infections. Trans. Am. Clin. Climatol. Assoc., 117: 75-84.

Washington, W.C., Stephen, D.A., William, M.J., Elmer, W.K., Gary, W.P., Paul, C.S., et al. 1997. Introduction to microbiology. In Nancy Peterson (Editor), Koneman'scolor Atlas and Textbook of Diagnostic Microbiology (67-111).USA: Lippincott Williams \& Wilkins.

\section{How to cite this article:}

Odimayo, M.S., Joseph Adejoke Kadijat, S.I. Nwadioha and Olabiyi Olugbenga Enoch. 2016. Antibiotic Profile of Urinary Pathogens in a Tertiary Hospital, in Ekiti State, Nigeria. Int.J.Curr.Microbiol.App.Sci. 5(9): 779-787. doi: http://dx.doi.org/10.20546/ijcmas.2016.509.089 